\begin{tabular}{l} 
2. To: (Receiving Organization) \\
Distribution \\
\hline 5. Proj./Prog./Dept./Div.: \\
TWRS \\
\hline 8 Originator Remarks:
\end{tabular}

8. Originator Remarks:

For approval and release.
3. From: (Originating Organization) R. D. Claghorn

6. Design Authority/ Design Agent/Cog. Engr.:

$$
\text { R. D. Claghorn }
$$

4. Related EDT No.: NA

7. Purchase Order No.: NA

9. Equip./Component Ho.: NA

10. Systen/Bldg./Facility: NA

11. Receiver Remarks: 11A, Design Baseline Document? [] Yes [X] Ho
12. Major Assm. Dug. No.: NA

13. Permit/Permit Application No.: NA

14. Required Response Date:

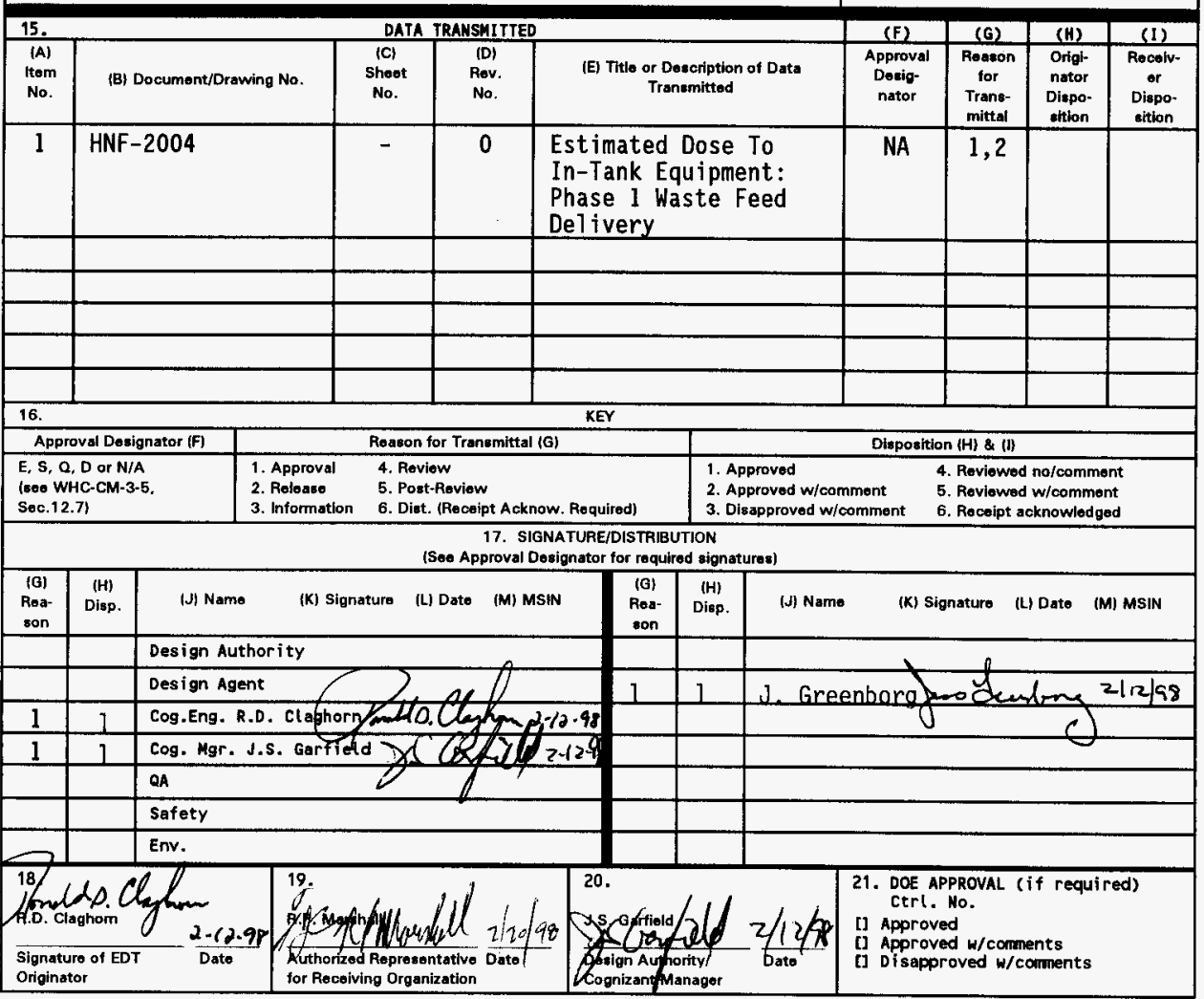

BD-7400-172-2 (05/96) GEF097 


\title{
Estimated Dose To In-Tank Equipment: Phase 1 Waste Feed Delivery
}

\author{
R.D. Claghorn \\ Numatec Hanford Corporation, Richland, WA 99352 \\ U.S. Department of Energy Contract DE-ACO6-96RL13200
}
EDT/ECN: $622703 \quad$ UC: 721
Org Code: 8C451 Charge Code: D2D21
B\&R Code: EW3130010 Total Pages: 33

Key Words: analysis, radiation dose, submerged, double-shell tank waste, in-tank equipment

Abstract: This analysis estimates the radiation dose to the equipment that will be submerged in double-shell tank waste. The results of this analysis are intended to be the basis for specifications for in-tank equipment.

The scope of this analysis is limited to the new equipment required for the delivery of waste feed to Phase 1 private contractors. Phase 1 refers to the first of a two-phase plan to privatize the remediation of Hanford's tank waste. The focus of this analysis is on waste feed delivery because of the extraordinarily high cost of any failure that would lead to the interruption of a steady flow of feed to the private contractors.

TRADEMARK DISCLAIMER. Reference herein to any specific comercial product, process, or service by trade name, trademark, manufacturer, or otherwise, does not necessarily constitute or imply its endorsement, recommendation, or favoring by the United States Goverment or any agency thereof or its contractors or subcontractors.

Printed in the United States of America. To obtain copies of this document, contact: Document Control Services, P.O. Box 950, Mailstop H6-08, Richland WA 99352, Phone (509) 372-2420; Fax (509) 376-4989.
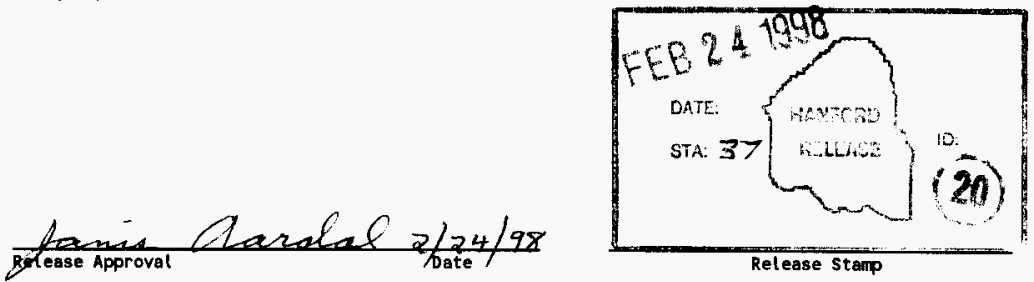
HNF-2004

Revision 0

\title{
ESTIMATED DOSE TO IN-TANK EQUIPMENT: \\ PHASE 1 WASTE FEED DELIVERY
}

February 1998

\author{
R. D. Claghorn \\ Numatec Hanford Corporation \\ Richland, Washington
}

Prepared for

U.S. Department of Energy

Richland, Washington 
HNF-2004

Revision 0

This page intentionally left blank. 
HNF-2004

Revision 0

CONTENTS

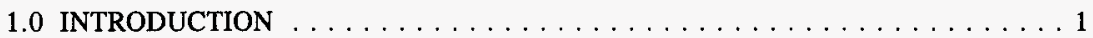

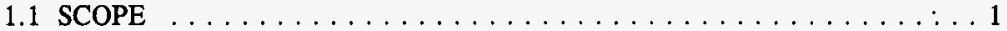

1.2 BACKGROUND $\ldots \ldots \ldots \ldots \ldots \ldots \ldots \ldots \ldots \ldots$

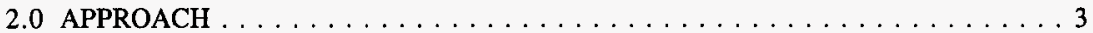

2.1 ESTIMATE OF RADIONUCLIDE CONTENT $\ldots \ldots \ldots \ldots \ldots \ldots \ldots$

2.2 CONTRIBUTION OF SPECIFIC RADIONUCLIDES $\ldots \ldots \ldots \ldots \ldots 3$

2.3 ESTIMATING THE DURATION OF EQUIPMENT EXPOSURE . . . . . . 4

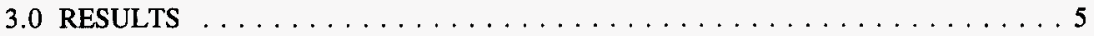

4.0 ESTIMATED IMPACT OF CHANGES TO SOURCE TERM INFORMATION $\ldots \ldots 7$

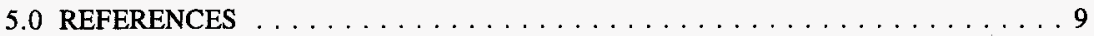

APPENDIX

A - RADIONUCLIDE INVENTORIES FOR EACH OF THE TANKS INVOLVED IN WASTE FEED DELIVERY FOR PHASE $1 \ldots \ldots \ldots \ldots$ A-1

\section{LIST OF TABLES}

1. Estimated Dose to Equipment Submerged in Phase I Intermediate Waste Feed Staging

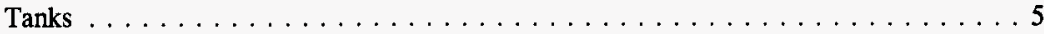

2. Estimated Dose to Equipment Submerged in Phase I Low-activity Waste Feed Tanks. . . 5

3. Estimated Dose to Equipment Submerged in Phase I High-level Waste Feed Tanks $\ldots . .6$ 
HNF-2004

Revision 0

\section{LIST OF TERMS}

DST Double-shell tank

HLW High-level waste

HTWOS Hanford Tank Waste Operations Simulator

SST Single-shell tank

TWRSO\&UP Tank Waste Remediation System Operations and Utilization Plan 
HNF-2004

Revision 0

\section{ESTIMATED DOSE TO IN-TANK EQUIPMENT: PHASE I WASTE FEED DELIVERY}

\subsection{INTRODUCTION}

This analysis estimates the radiation dose to the equipment that will be submerged in double-shell tank (DST) waste. The results of this analysis are intended to be the basis for specifications for in-tank equipment.

\subsection{SCOPE}

The scope of this analysis is limited to the new equipment required for the delivery of waste feed to Phase 1 private contractors. Phase 1 refers to the first of a two-phase plan to privatize the remediation of Hanford's tank waste. The focus of this analysis is on waste feed delivery because of the extraordinarily high cost of any failure that would lead to the interruption of a steady flow of feed to the private contractors.

\subsection{BACKGROUND}

The projects that will contribute to the various elements of the Phase 1 waste feed delivery system are currently using different source terms. Project W-058, the Replacement of the Cross-Site Transfer System, and W-314, Tank Farm Restoration and Safe Operations, have adopted information from the Tank Waste Composition and Atmospheric Dispersion Coefficients for Use in Safety Analysis Consequence Assessments (Van Keuren 1996). That document describes a rather extensive analysis of tank waste, both single-shell tank (SST) waste and DST waste. The SST waste is applicable to those projects because the current plan is to retrieve all of the waste in SSTs and pipe it to DSTs to await final processing.

The Tank Waste Composition (Van Keuren 1996) analysis derives bounding values for liquids and solids. As might be expected, there is a significant difference between the concentration of radionuclides in waste solids and the concentration in the liquid. By inspection of the tables in the referenced document, most radionuclides of concern to the environment are more concentrated in the solids layer. Since most transfers are limited to 30 percent solids or less, the bounding source term for a waste transfer is based on the idea that the waste consists of 33 percent solids and 67 percent liquids. That limitation, of course, doesn't apply to equipment that's immersed in waste. Furthermore, most of the radionuclides of concern to the environment aren't significant to the durability of in-tank equipment.

Other projects use measured values for their source terms. Project W-211, the Initial Tank Retrieval System, adopted its source term from Project W-151, the Tank 101-AZ Waste 
HNF-2004

Revision 0

Retrieval System. The W-151 source term is based on values that were measured during radiation surveys. The engineer for Project W-151 recalls that the dose rate information for the Tank 101-AZ Waste Retrieval System Functional Design Criteria (Nordquist 1997) was provided by engineers working in tank farm operations.

The source term for Project W-211, as defined in the current version of the FDC and in the procurement specification, is $500 \mathrm{R} / \mathrm{hr}$. This was the original source term for $\mathrm{W}-151$. Project W-151 now uses $670 \mathrm{R} / \mathrm{hr}$ even though the Dose Rate Analysis for Tank AZ-101, Project W-151 (Schwarz et al. 1994) states that $1000 \mathrm{R} / \mathrm{hr}$ has been measured in tank 241-AZ-101.

Documentation for Project W-058, which has been adopted for use by Project W-314, states that the dose rate for equipment immersed in HLW is 10,000 R/hr (Henderson 1996). This is about 10 times what was measured in tank 241-AZ-101. The large difference between the measured value and the one that was calculated is attributed to the conservatism inherent in the use of a "bounding" tank composition for dose rate calculations. 
HNF-2004

Revision 0

\subsection{APPROACH}

The overall approach to this analysis is to estimate radiation fields in each DST by comparing their radionuclide content with the content in 241-AZ-101. Tank 241-AZ-101 is used as a reference because it has credible documentation for both content and measured dose rates. The details of this approach are further explained in the following sections.

\subsection{ESTIMATE OF RADIONUCLIDE CONTENT}

The content of each DST during Phase 1 is estimated using the Hanford Tank Waste Operations Simulator (HTWOS). The HTWOS is a computer program designed to track the components of the waste as the waste is transferred from tank to tank to the private contractors. The HTWOS uses recent, if not the most recent, characterization data to calculate the initial inventory for each tank. To generate the graphics in Appendix A, tank contents were quantified for January 1, 2000, and before and after each transfer into or out of a DST.

\subsection{CONTRIBUTION OF SPECIFIC RADIONUCLIDES}

Of all the isotopes listed in tank inventories, the Tank Waste Composition (Van Keuren 1996) analysis identifies only four that are strong gamma emitters. These isotopes are ${ }^{137} \mathrm{Cs} /{ }^{137} \mathrm{mBa}$, ${ }^{60} \mathrm{Co},{ }^{154} \mathrm{Eu}$ and ${ }^{155} \mathrm{Eu}$. The contribution of these four isotopes amounts to more than 98 percent of the total quantity of gamma energy emitted from all of the radionuclides. Of those four isotopes, ${ }^{137} \mathrm{Cs}$ is by far the most prevalent in the DST inventory.

This analysis uses ${ }^{137} \mathrm{Cs}$ and ${ }^{90} \mathrm{Sr}$ as indicators of the radionuclide content in each tank. The HTWOS software tracks the quantity of both liquids and solids in a tank. Cesium and strontium are the most prevalent radionuclides in the inventory. Cesium is usually dissolved in tank liquids whereas strontium salts are often insoluble and are, therefore, usually much more concentrated in tank solids.

The contribution of $\mathrm{Sr}$ to gamma energy is assigned a weight that is $1 / 75$ th of the contribution of ${ }^{137} \mathrm{Cs}$ on a per-Curie basis. Most of the ${ }^{137} \mathrm{Cs}$ energy is emitted as a gamma ray whereas almost all of the ${ }^{90} \mathrm{Sr}$ energy is emitted as beta radiation. Only a small fraction of the beta is converted to photon radiation through the bremsstrahlung effect. The quantity converted is directly proportional to the atomic number of the surrounding material (Roetman 1997). Using an estimate of the dose from cesium and strontium capsules as a point of reference, it appears that the gamma attributed to strontium is about $1 / 75$ th as significant as cesium on a per-Curie basis (Schwarz 1996). 
HNF-2004

Revision 0

\subsection{ESTIMATING THE DURATION OF EQUIPMENT EXPOSURE}

Appendix H of the Tank Waste Remediation System Operations and Utilization Plan (TWRSO\&UP) (Kirkbride et al. 1997) documents the baseline completion date for the tank upgrades required to support Phase 1 waste feed delivery. For the low-activity waste (LAW) feed source tanks, the baseline completion date is generally 6 months before the waste is scheduled for transfer to the intermediate waste feed staging tanks. The Supplement 2 to Title I Design Summary Report (ICF KHC 1995) shows that construction for each tank usually requires about two years. It is assumed that some equipment, such as mixers, are installed early in the construction phase of the project. Therefore, the duration of exposure for equipment installed in sources of LAW feed is assumed to be $2 \frac{1 / 2}{\mathrm{yr}}$.

New equipment installed in the HLW feed source tanks will be subject to an extended exposure. In addition to the two years before initial operations, each of the HLW source tanks will perform sludge washing operations for nearly a year and then they will transfer feed to the HLW processing facility a little at a time. The new equipment installed in these tanks will, therefore see 5 to $7 \frac{1}{2}$ yr of exposure during Phase 1 feed delivery operations.

The intermediate waste feed staging tanks, 241-AP-102 and 241-AP-104, are involved in almost every transfer of LAW feed. Therefore, they will see the longest duration of exposure $(9 \mathrm{yr})$. 


\subsection{RESULTS}

The results of this analysis are summarized in Tables 1,2 and 3. Additional detail is provided by the figures attached as Appendix A.

Table 1. Estimated Dose to Equipment Submerged in Phase 1 Intermediate Waste Feed Staging Tanks.

\begin{tabular}{|l|l|l|}
\hline \multicolumn{1}{|c|}{ Tank } & \multicolumn{1}{c|}{$\begin{array}{c}\text { Peak dose rate, } \\
\mathrm{R} / \mathrm{hr}\end{array}$} & \multicolumn{1}{|c|}{$\begin{array}{c}\text { Total integrated } \\
\text { Dose, } \mathrm{R}\end{array}$} \\
\hline 241-AN-102 & 150 & $3.3 \mathrm{E} 06$ \\
\hline 241-AN-103 & 260 & $5.3 \mathrm{E} 06$ \\
\hline $241-\mathrm{AN}-104$ & 350 & $4.7 \mathrm{E} 06$ \\
\hline $241-\mathrm{AN}-105$ & 200 & $3.9 \mathrm{E} 06$ \\
\hline $241-\mathrm{AN}-106$ & 140 & $3.0 \mathrm{E} 06$ \\
\hline $241-\mathrm{AN}-107$ & 170 & $3.6 \mathrm{E} 06$ \\
\hline $241-\mathrm{AW}-101$ & 350 & $5.6 \mathrm{E} 06$ \\
\hline $241-\mathrm{SY}-101$ & 130 & $2.8 \mathrm{E} 06$ \\
\hline $241-\mathrm{SY}-102$ & 80 & $7.6 \mathrm{E} 05$ \\
\hline $241-\mathrm{SY}-103$ & 130 & $1.6 \mathrm{E} 06$ \\
\hline
\end{tabular}

Table 2. Estimated Dose to Equipment Submerged in Phase 1 Low-Activity Waste Feed Tanks.

\begin{tabular}{|c|l|l|}
\hline Tank & $\begin{array}{c}\text { Peak dose rate, } \\
\mathrm{R} / \mathrm{hr}\end{array}$ & \multicolumn{1}{c|}{$\begin{array}{c}\text { Total integrated } \\
\text { Dose, } \mathrm{R}\end{array}$} \\
\hline 241-AP-102 & 340 & $7.1 \mathrm{E} 06$ \\
\hline 241-AP-104 & 340 & $8.1 \mathrm{E} 06$ \\
\hline
\end{tabular}


HNF-2004

Revision 0

Table 3. Estimated Dose to Equipment Submerged in

Phase 1 High-level Waste Feed Tanks.

\begin{tabular}{|l|l|l|}
\hline \multicolumn{1}{|c|}{ Tank } & \multicolumn{1}{|c|}{$\begin{array}{c}\text { Peak dose rate, } \\
\mathrm{R} / \mathrm{hr}\end{array}$} & \multicolumn{1}{|c|}{$\begin{array}{c}\text { Total integrated } \\
\text { dose, } \mathrm{R}\end{array}$} \\
\hline 241-AY-101 & 1100 & $9.5 \mathrm{E} 07$ \\
\hline 241-AY-102 & 10 & $3.6 \mathrm{E} 05$ \\
\hline $241-\mathrm{AZ}-101$ & 1000 & $2.3 \mathrm{E} 07$ \\
\hline 241-AZ-102 & 580 & $1.3 \mathrm{E} 07$ \\
\hline
\end{tabular}


HNF-2004

Revision 0

\subsection{ESTIMATED IMPACT OF CHANGES TO SOURCE TERM INFORMATION}

It appears that the $500 \mathrm{R} / \mathrm{hr}$ source term currently specified in Project W-211 design documents is adequate for LAW source tanks and the intermediate waste feed staging tanks. For HLW source tanks, however, the $1,000 \mathrm{R} / \mathrm{hr}$ (measured) or the $10^{4} \mathrm{R} / \mathrm{hr}$ (calculated) source term used by Projects W-058 and W-314 appear to be more appropriate.

If the higher source term is adopted for HLW, the impacts to on-going projects are estimated to be rather minor. According to the engineers working on Project W-211, the materials used for construction are the best available (Rieck 1997). According to engineers for Project W-151, the operational life of any rubber or plastic component will be shorter in a higher radiation field. If the dose is actually $1000 \mathrm{R}$ instead of $670 \mathrm{R}$, the O-rings in the lower seals of the mixer will fail at $20,000 \mathrm{hrs}$ (instead of $30,000 \mathrm{hrs)}$ "forecasting the failure to occur 9/30/98" (Nordquist 1997). The consequences of that failure, however, are rather insignificant. It is estimated that approximately $2 \mathrm{~L} / \mathrm{hr}$ of water will leak into the tank while the mixer is running. That quantity would be negligible in a million-gallon tank. 
HNF-2004

Revision 0

This page intentionally left blank. 
HNF-2004

Revision 0

\subsection{REFERENCES}

Henderson, J. L., 1996, Project W-058 Cross Site Transfer System Revised Shielding Calculation Results, Memorandum no. W-058-076 to C. van Katwijk (May 13), ICF Kaiser Hanford Company, Richland, Washington.

ICF KHC, 1995, Supplement 2 to Title I Design Summary Report: Initial Tank Retrieval Systems Project W-211, WHC-SD-W211-TDR-001, Rev. 0B, Westinghouse Hanford Company, Richland, Washington.

Kirkbride, R. A., G. K. Allen, P. J. Certa, A. F. Manuel, R. M. Orme, L. W. Shelton, E. J. Slaathaug, R. S. Wittman, G. T. MacLean and D. L. Penwell, 1997, Tank Waste Remediation System Operation and Utilization Plan, HNF-SD-WM-SP-012, Rev. 0, Numatec Hanford Corporation, Richland, Washington.

Nordquist, E. M., 1987, Tank 101-AZ Waste Retrieval System Functional Design Criteria, HNF-SD-W151-FDC-001, Rev. 4, Numatec Hanford Company, Richland, Washington.

Nordquist, E. M., 1997, cc:mail to R. D. Claghorn (December 4), Numatec Hanford Corporation, Richland, Washington.

Rieck, C. A., 1997, personal communications with R. D. Claghorn (December 4), Numatec Hanford Corporation, Richland, Washington.

Roetman, V. E., 1997, cc:Mail to R. D. Claghorn (December 9), Fluor Daniel Northwest, Richland, Washington.

Schwarz, R. A., K. E. Hillesland and L. L. Carter, 1994, Dose Rate Analysis for Tank AZ-101, Project W-151, WHC-SD-W151-TI-002, Rev. 0, Westinghouse Hanford Company, Richland, Washington.

Schwarz, R. A., and E. H. Randklev, Dose Rate Calculations for Strontium Fluoride Capsules and Cesium Chloride Capsules and for Such Capsules as Overpacked for Disposal, WHC-SD-WM-TI-790, Rev. 0, Westinghouse Hanford Company, Richland, Washington.

Van Keuren, J. C., 1996 Tank Waste Composition and Atmospheric Dispersion Coefficients for Use in Safety Analysis Consequence Assessments, WHC-SD-WM-SARR-016, Rev. 2, Westinghouse Hanford Company, Richland, Washington. 
HNF-2004

Revision 0

This page intentionally left blank. 
HNF-2004

Revision 0

APPENDIX A

RADIONUCLIDE INVẸNTORIES FOR EACH OF THE TANKS

INVOLVED IN WASTE FEED DELIVERY FOR PHASE 1 
HNF-2004

Revision 0

This page intentionally left blank. 
HNF-2004

Revision 0

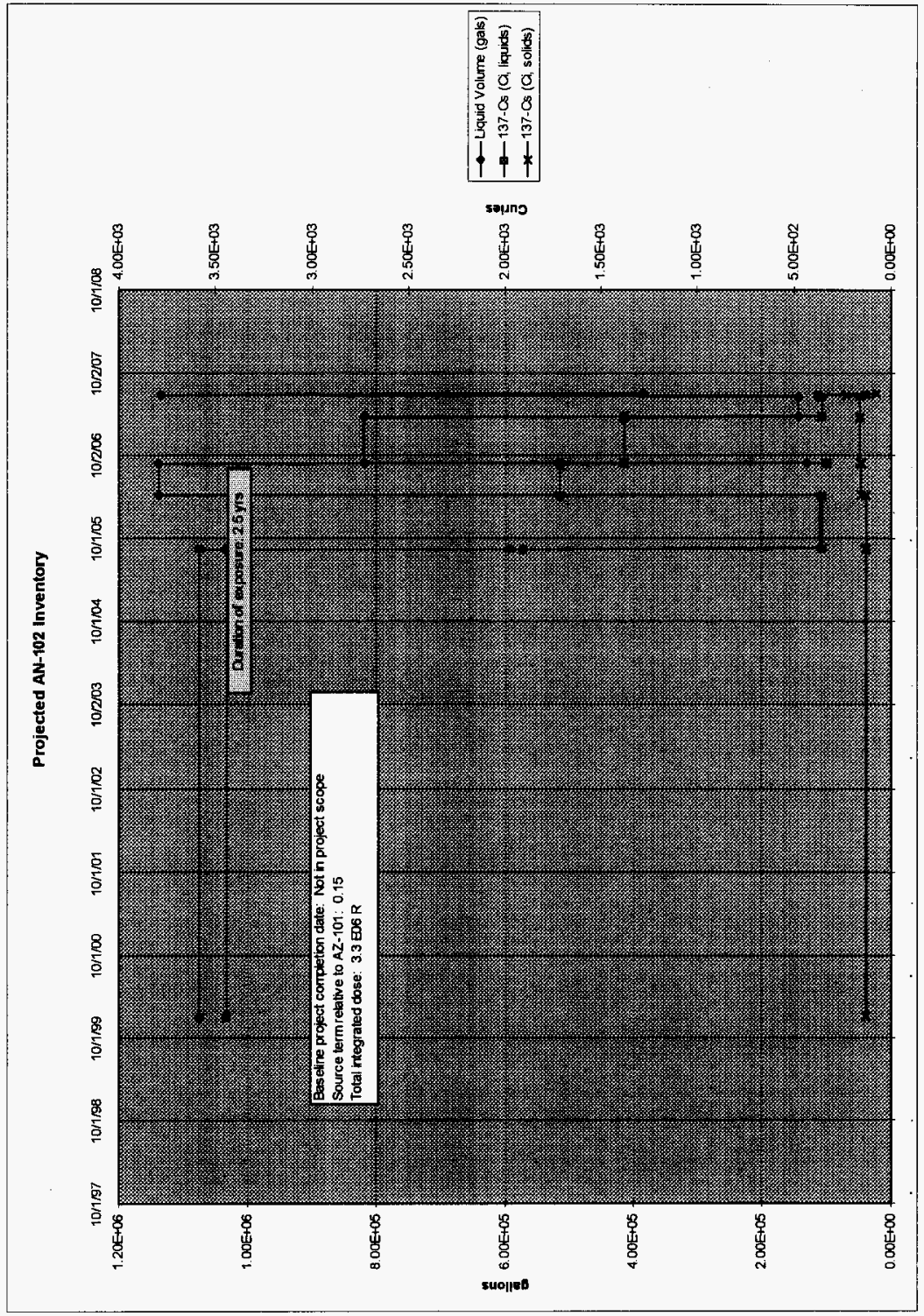


HNF-2004

Revision 0

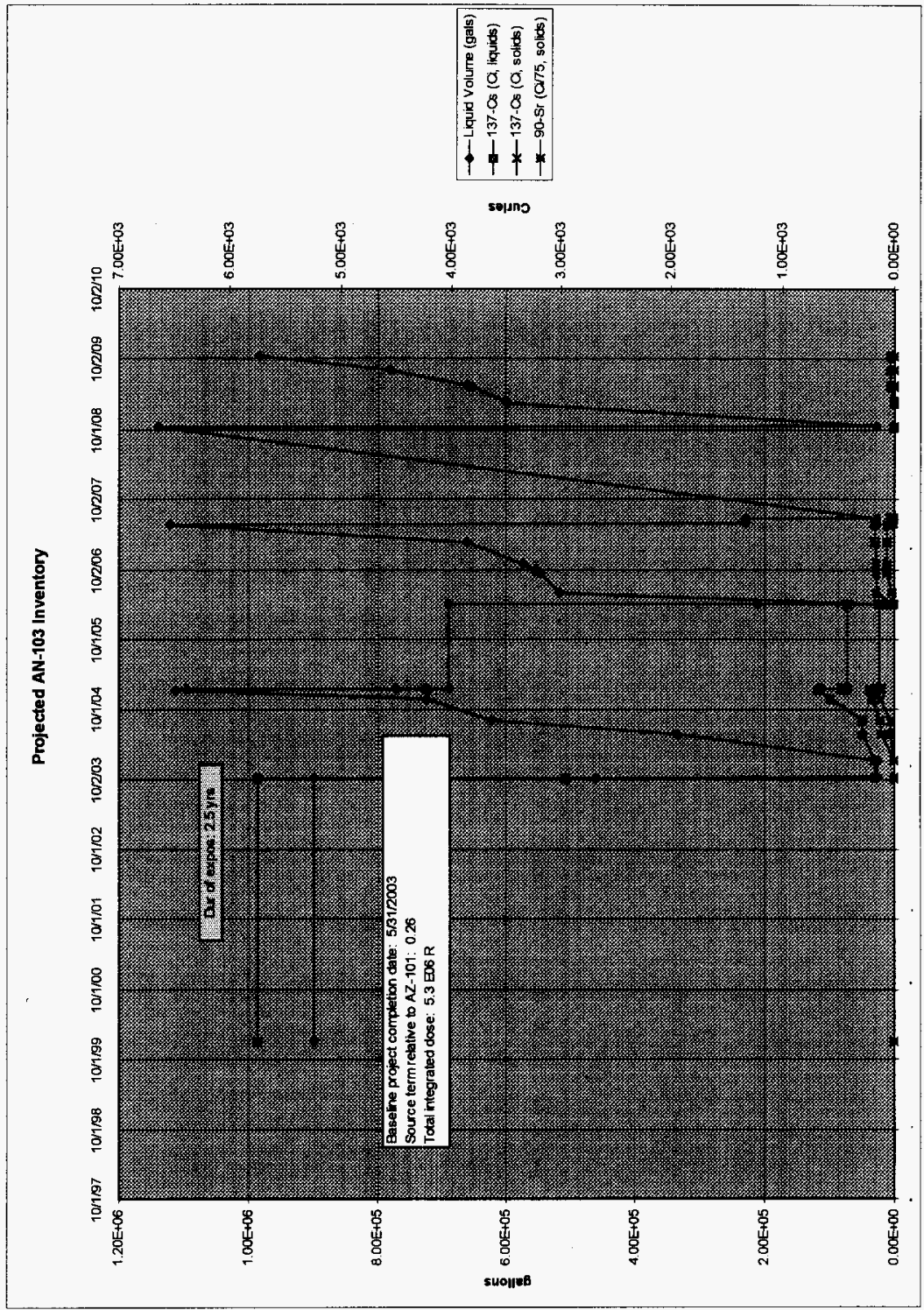


HNF-2004

Revision 0

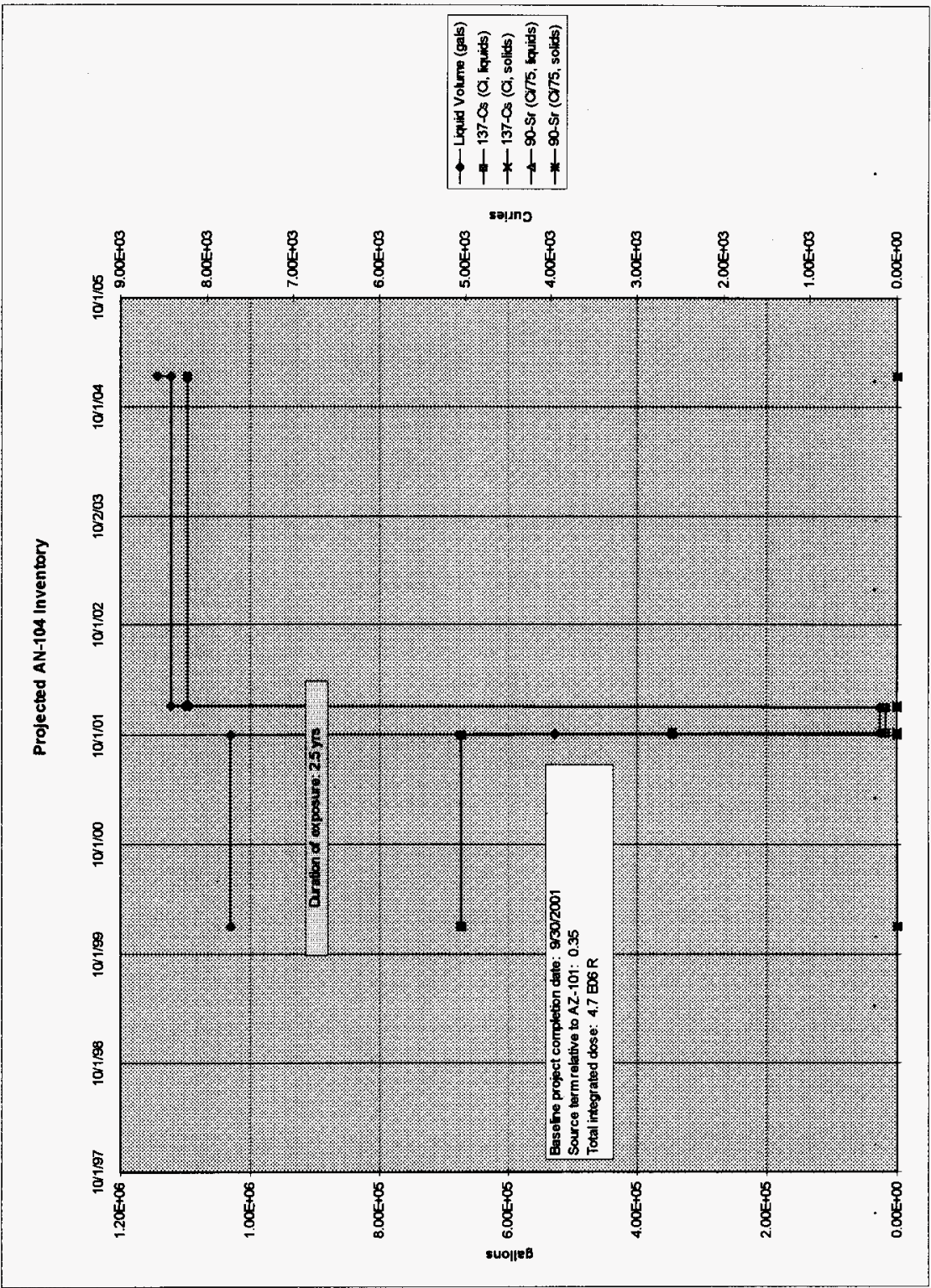


HNF-2004

Revision $\theta$
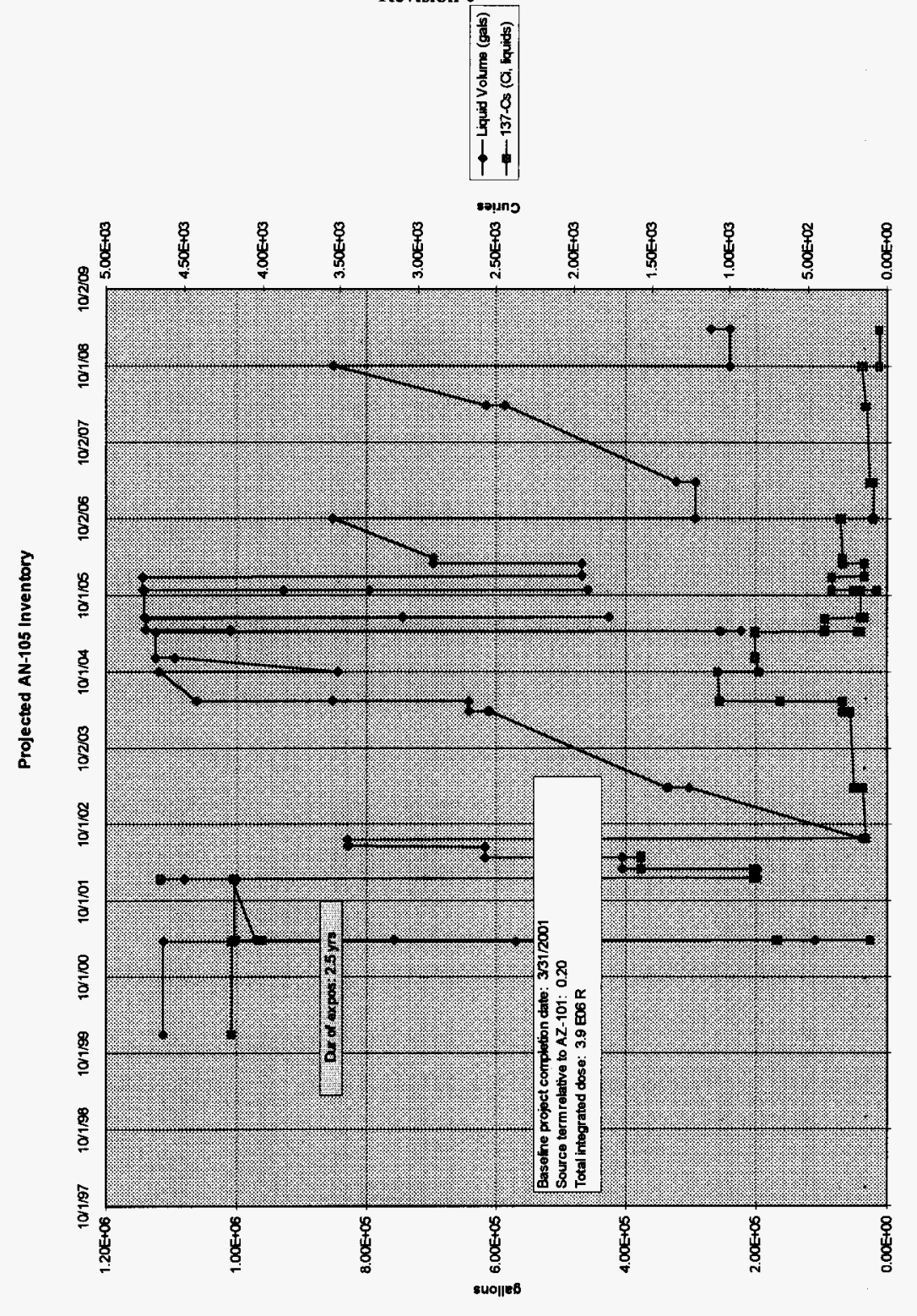
HNF-2004

Revision 0

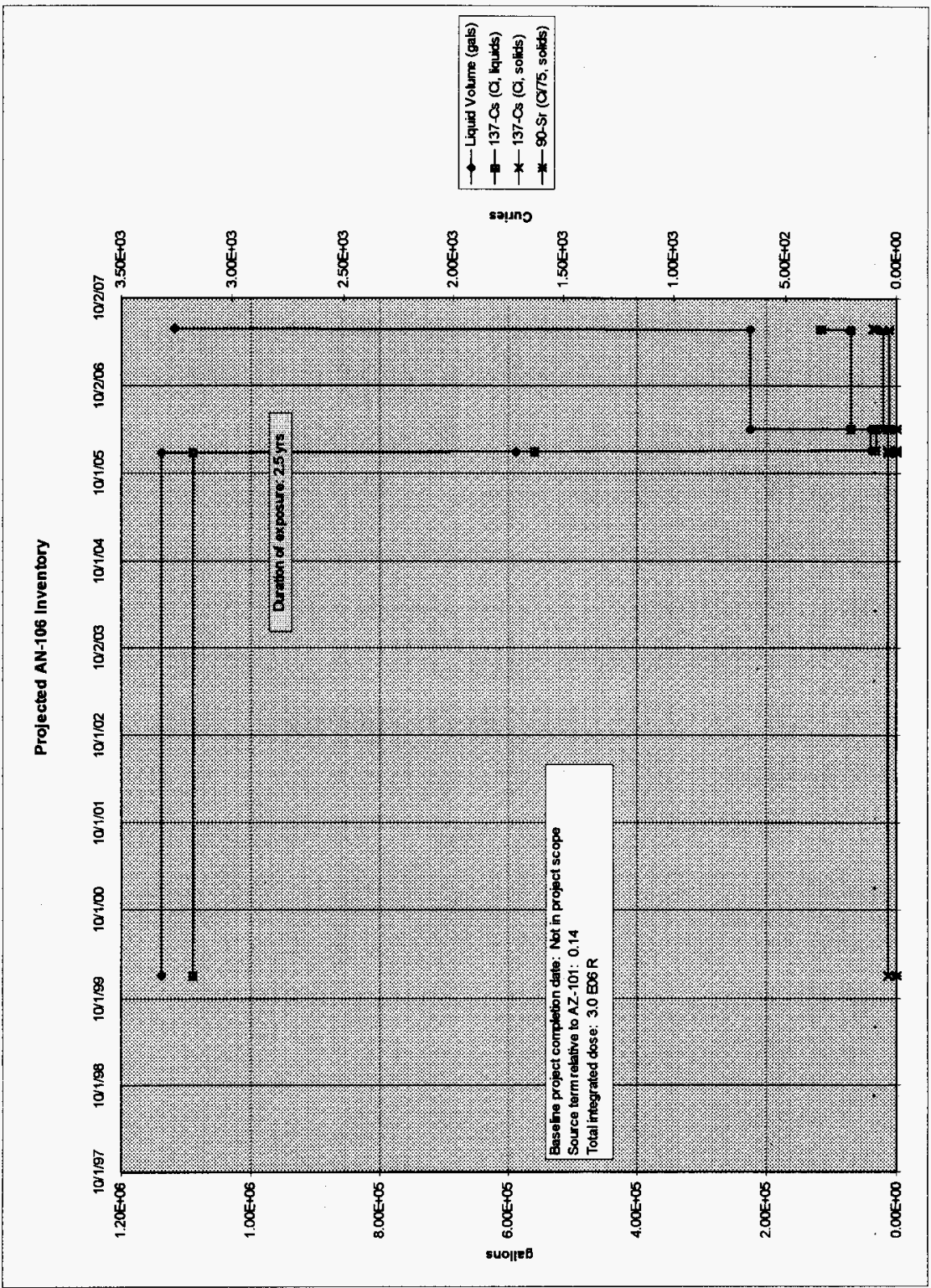


8-V $^{-\mathrm{V}}$

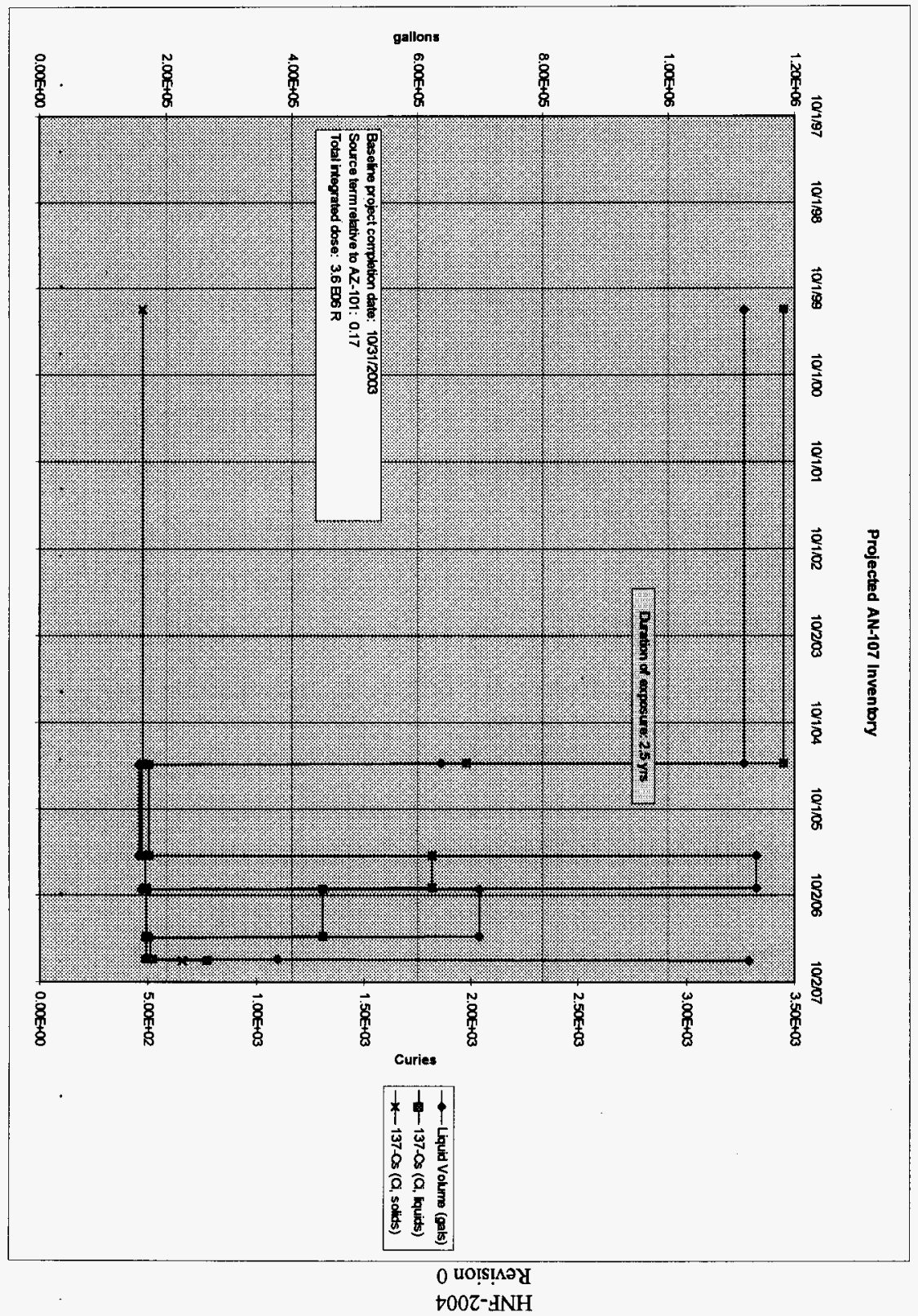


HNF-2004

Revision 0

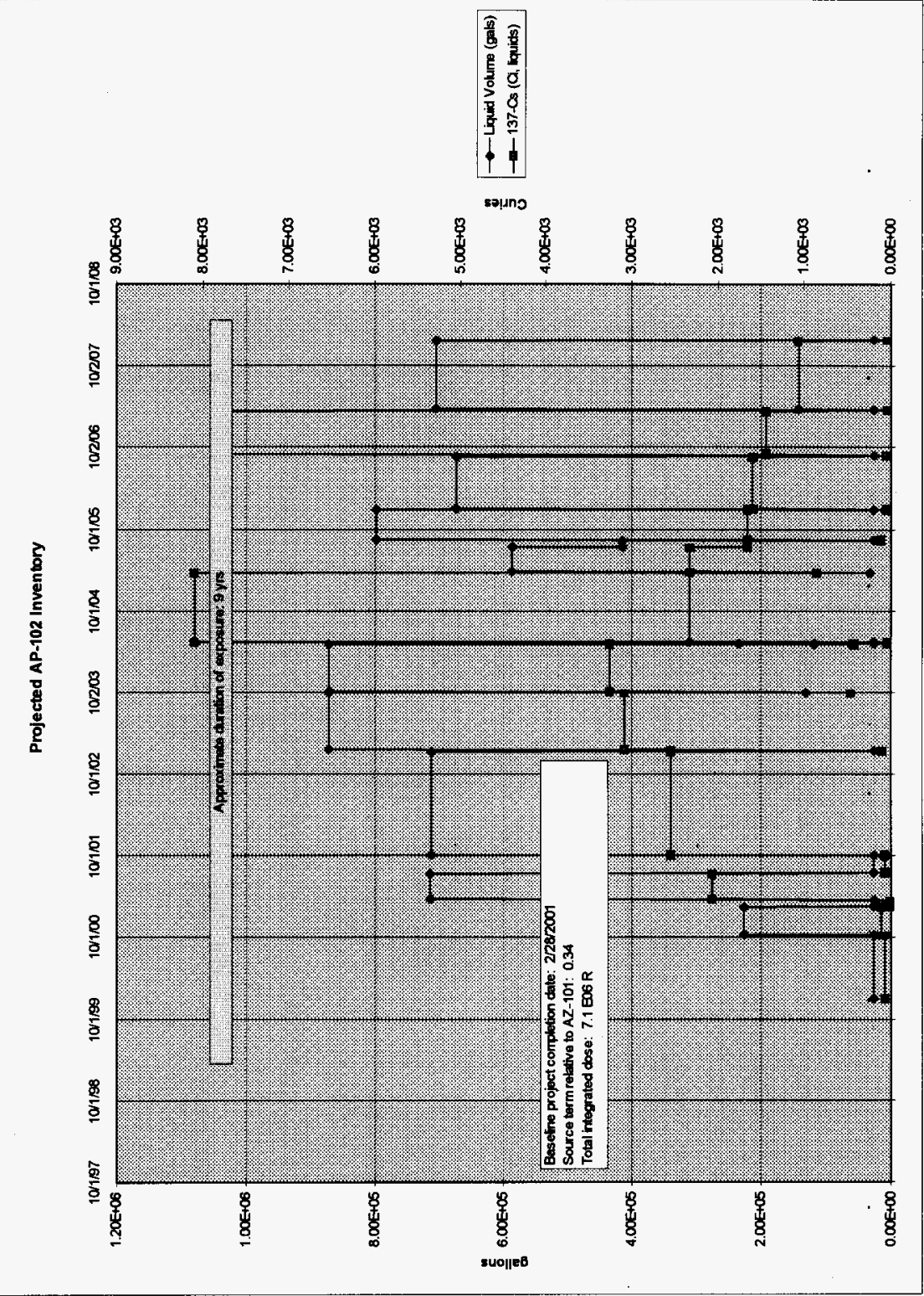


HNF-2004

Revision 0

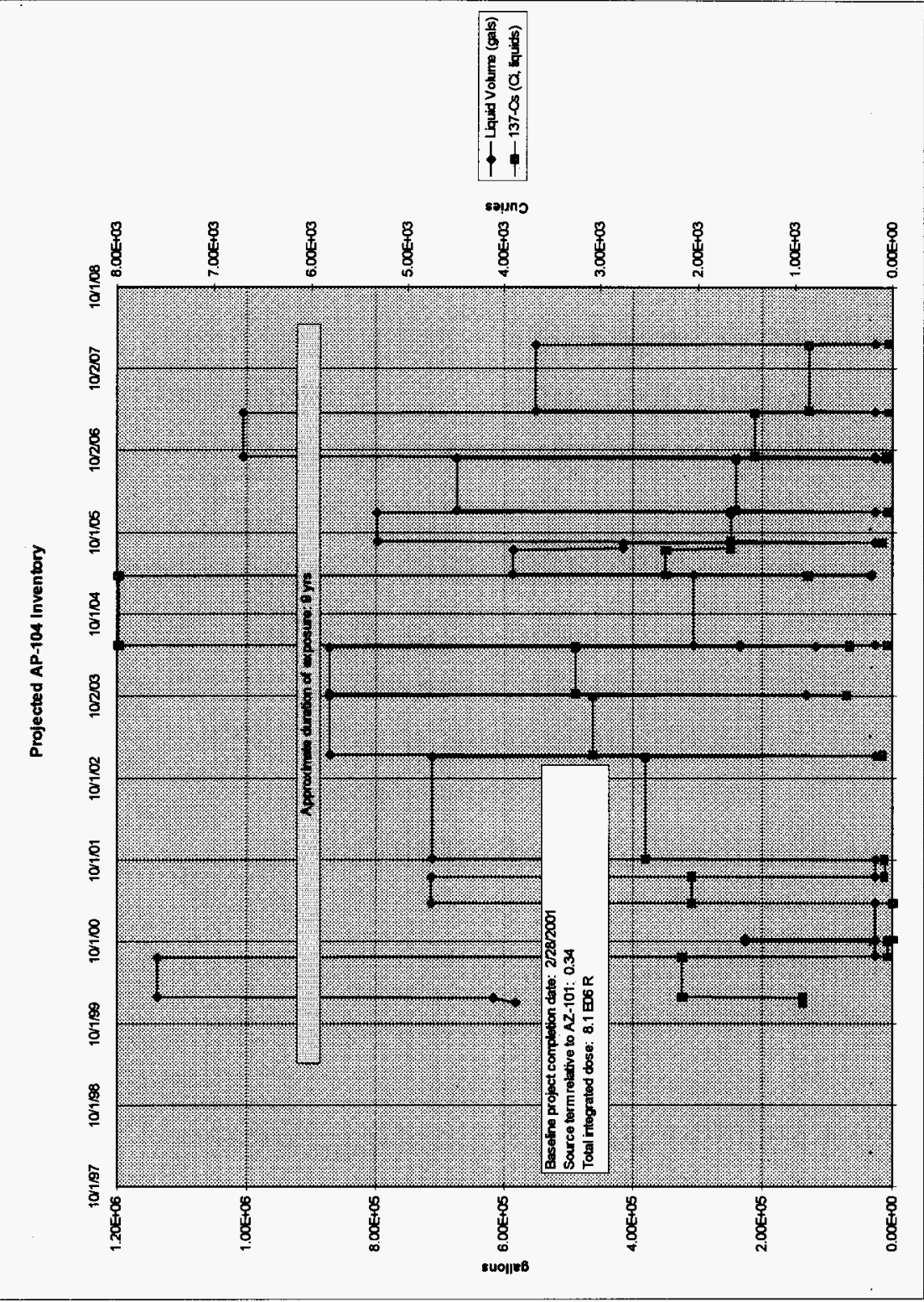




\section{HNF-2004}

Revision 0

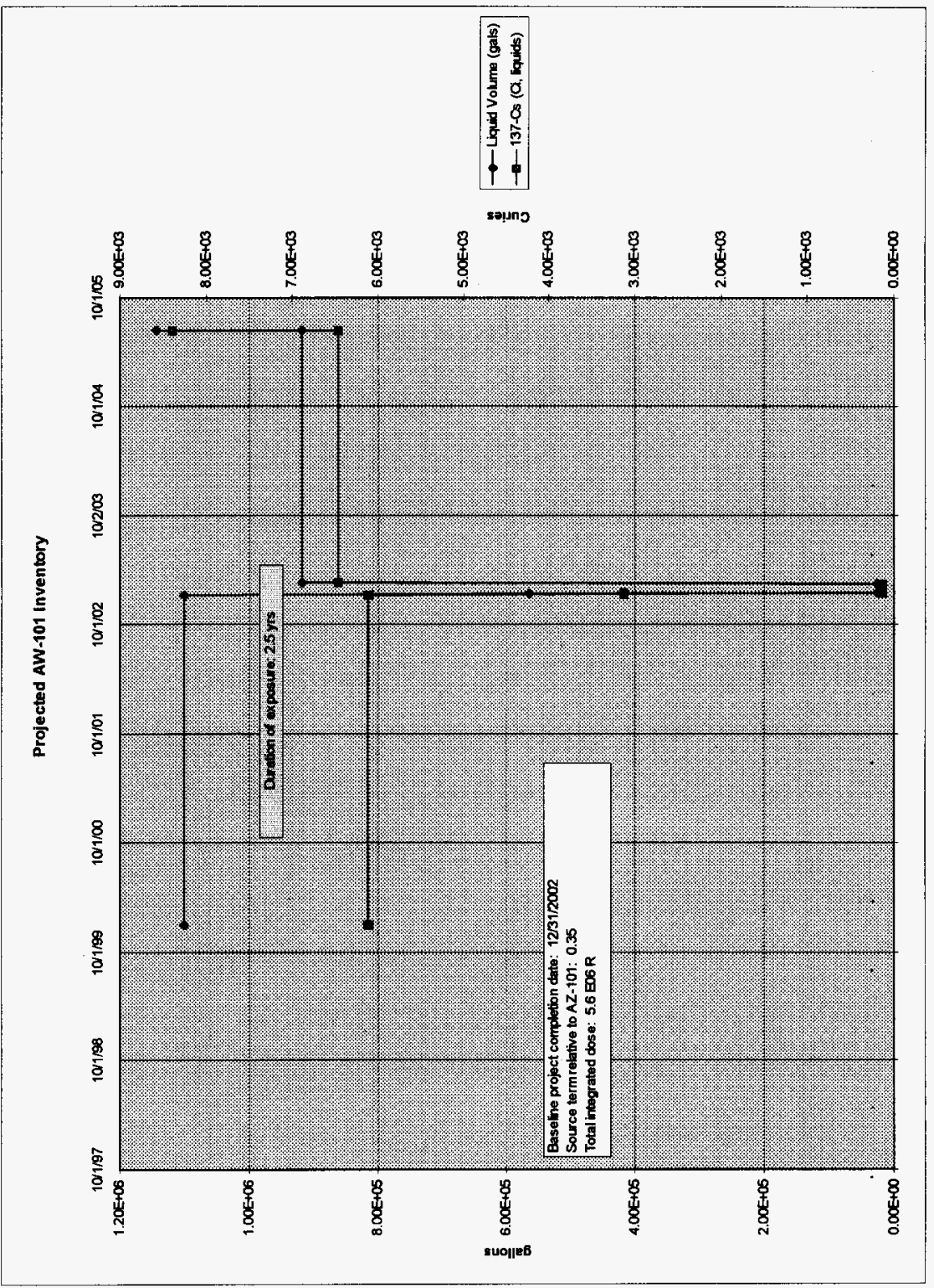


HNF-2004

Revision 0

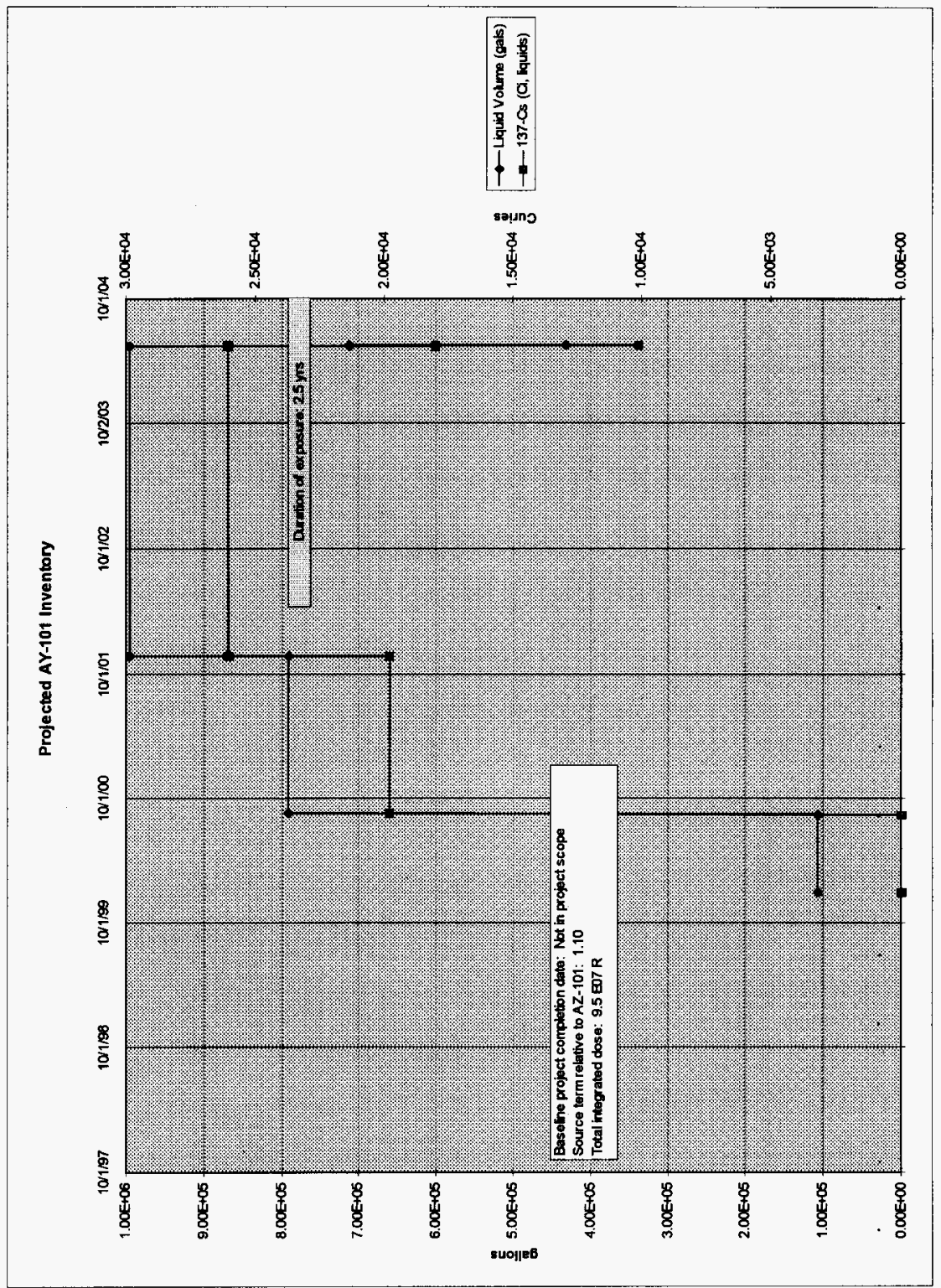


HNF-2004

Revision 0

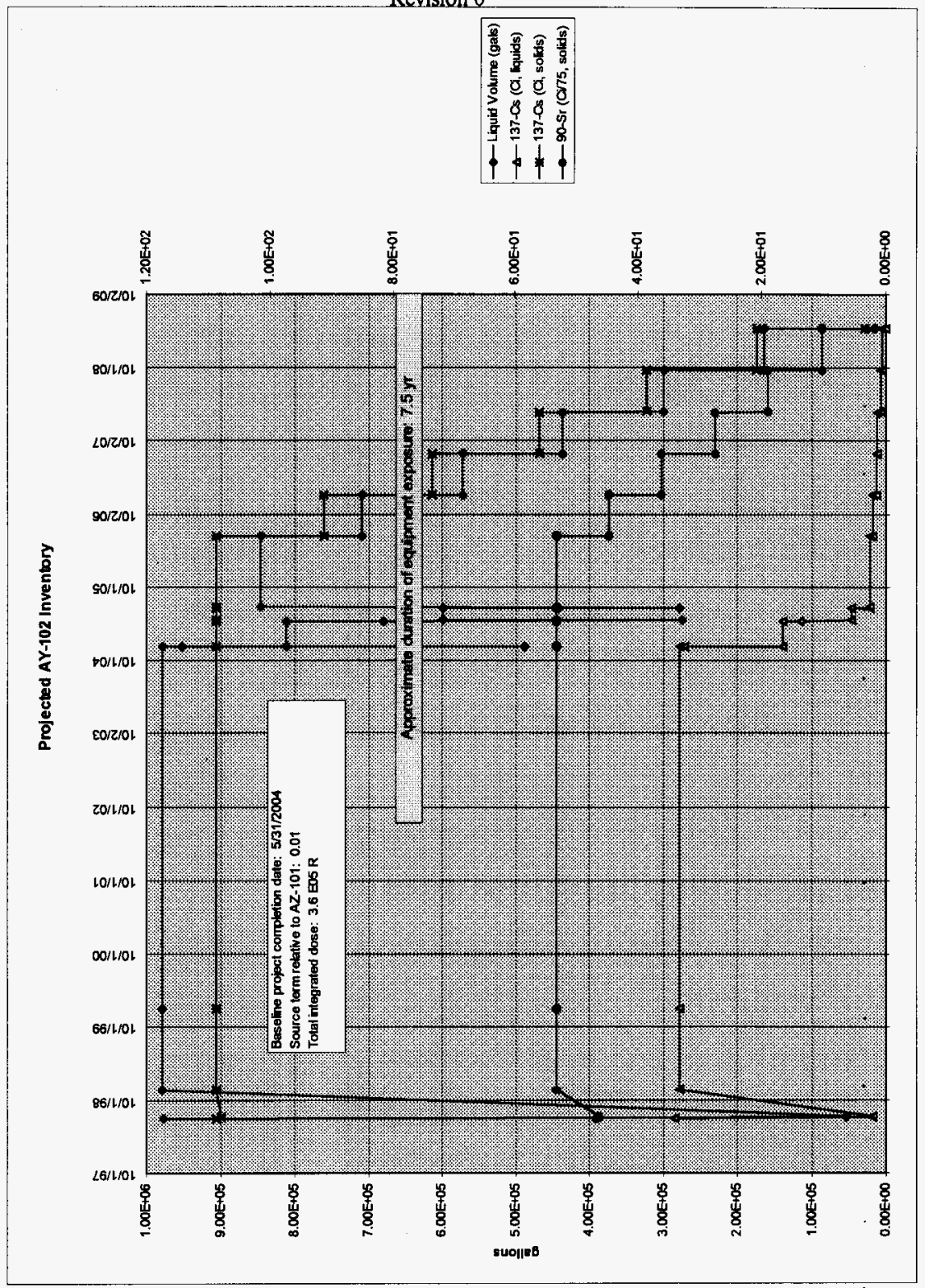

A-13 
HNF-2004

Revision 0

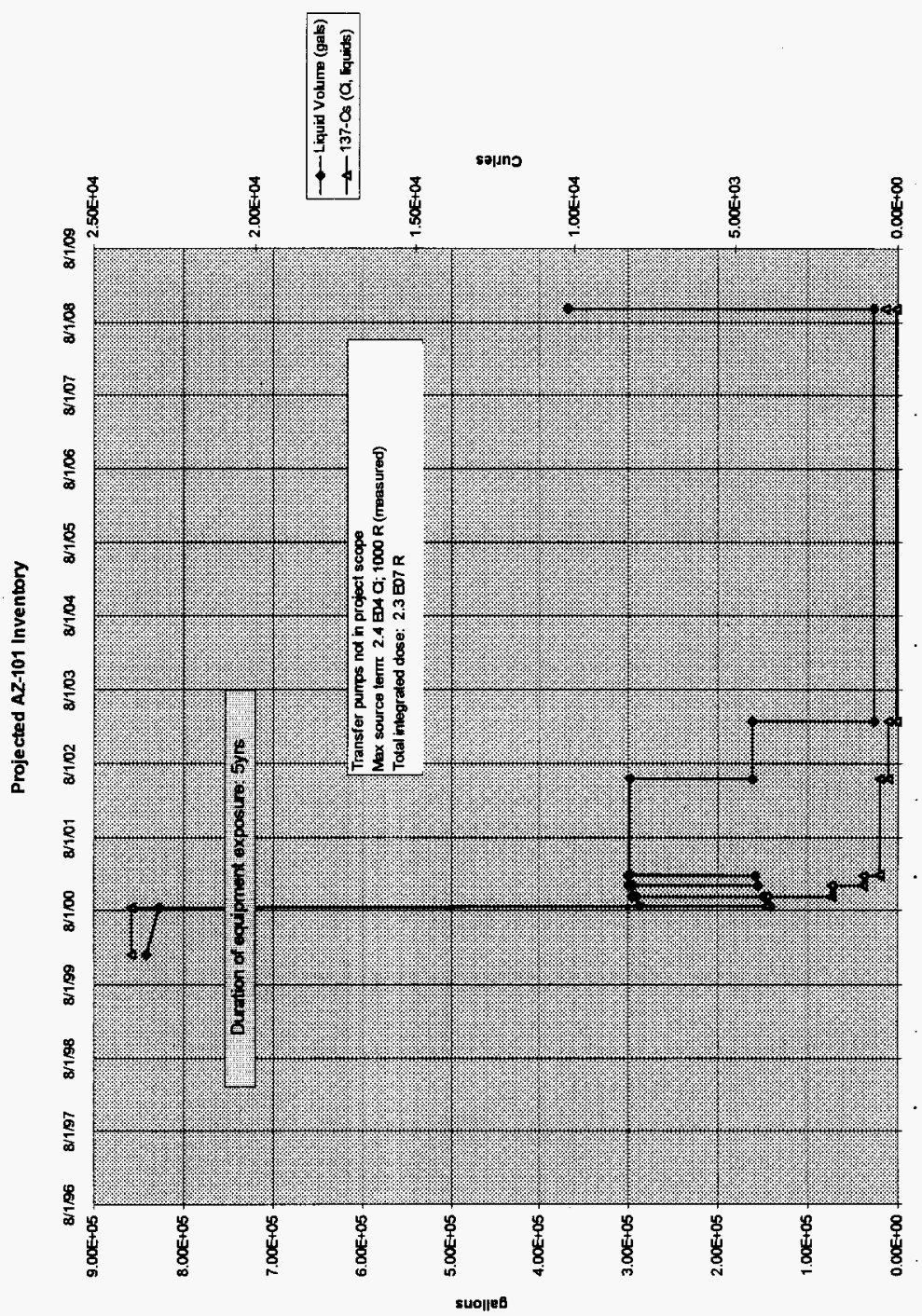


HNF-2004

Revision 0

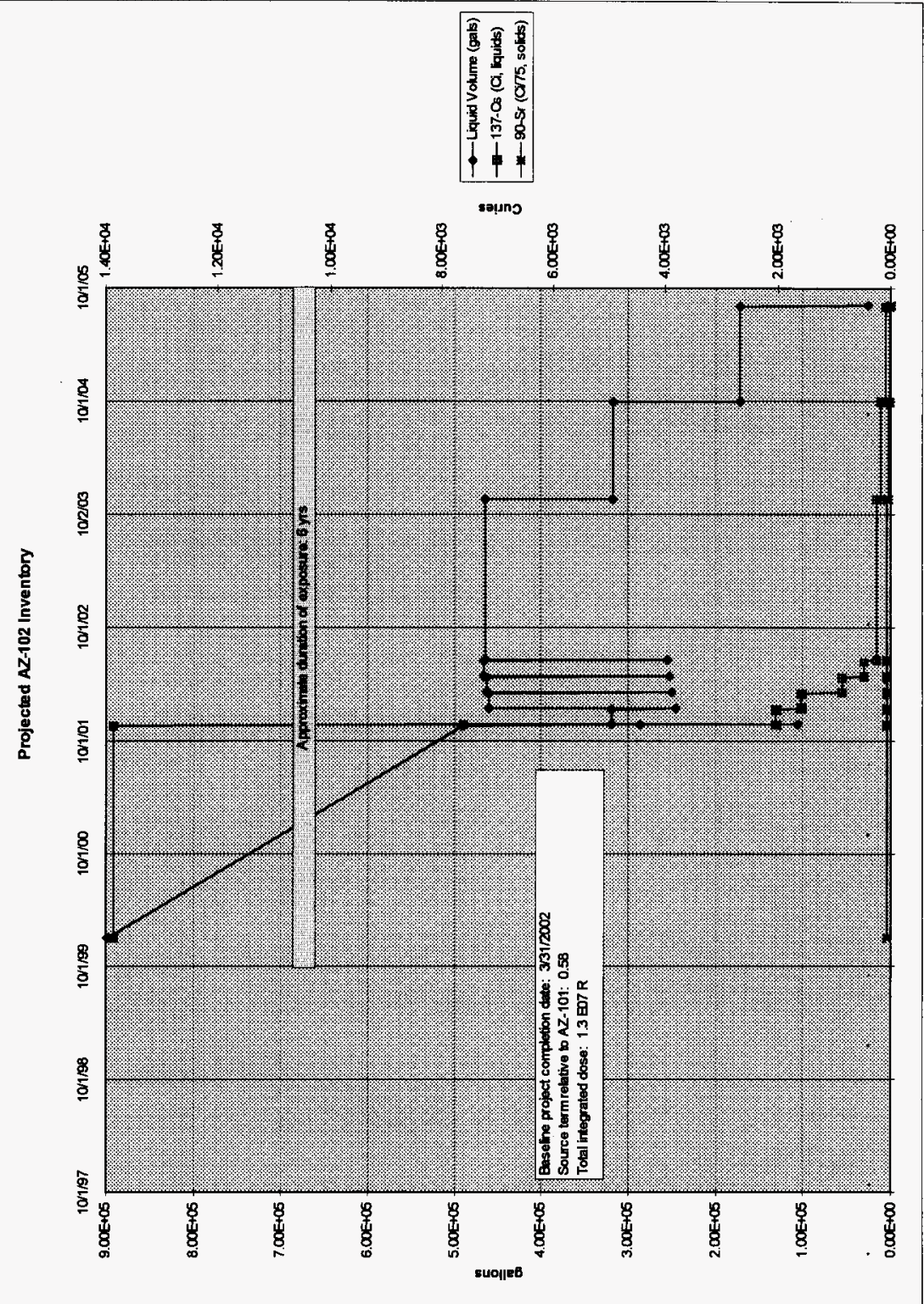


HNF-2004

Revision 0

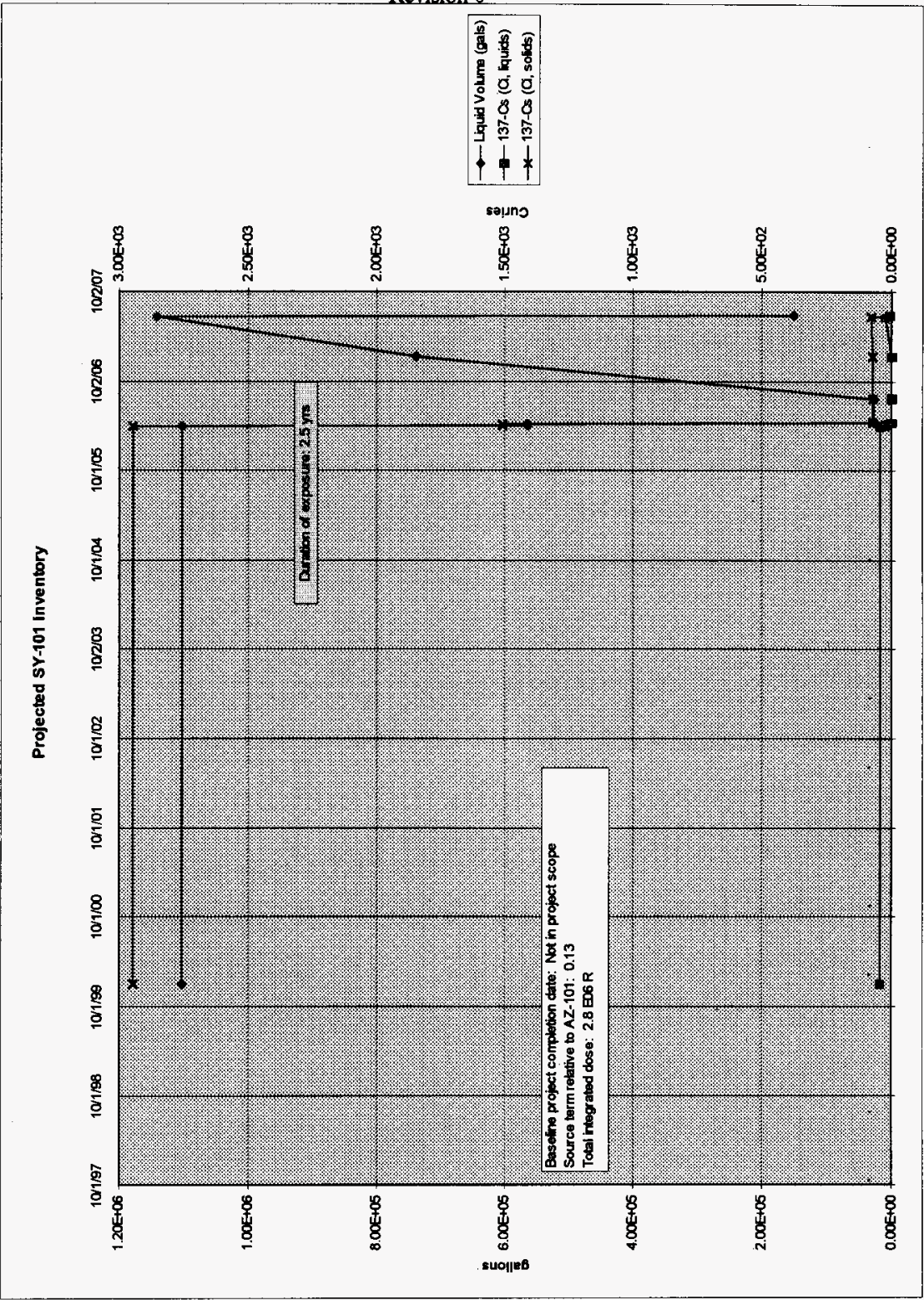


HNF-2004

Revision 0

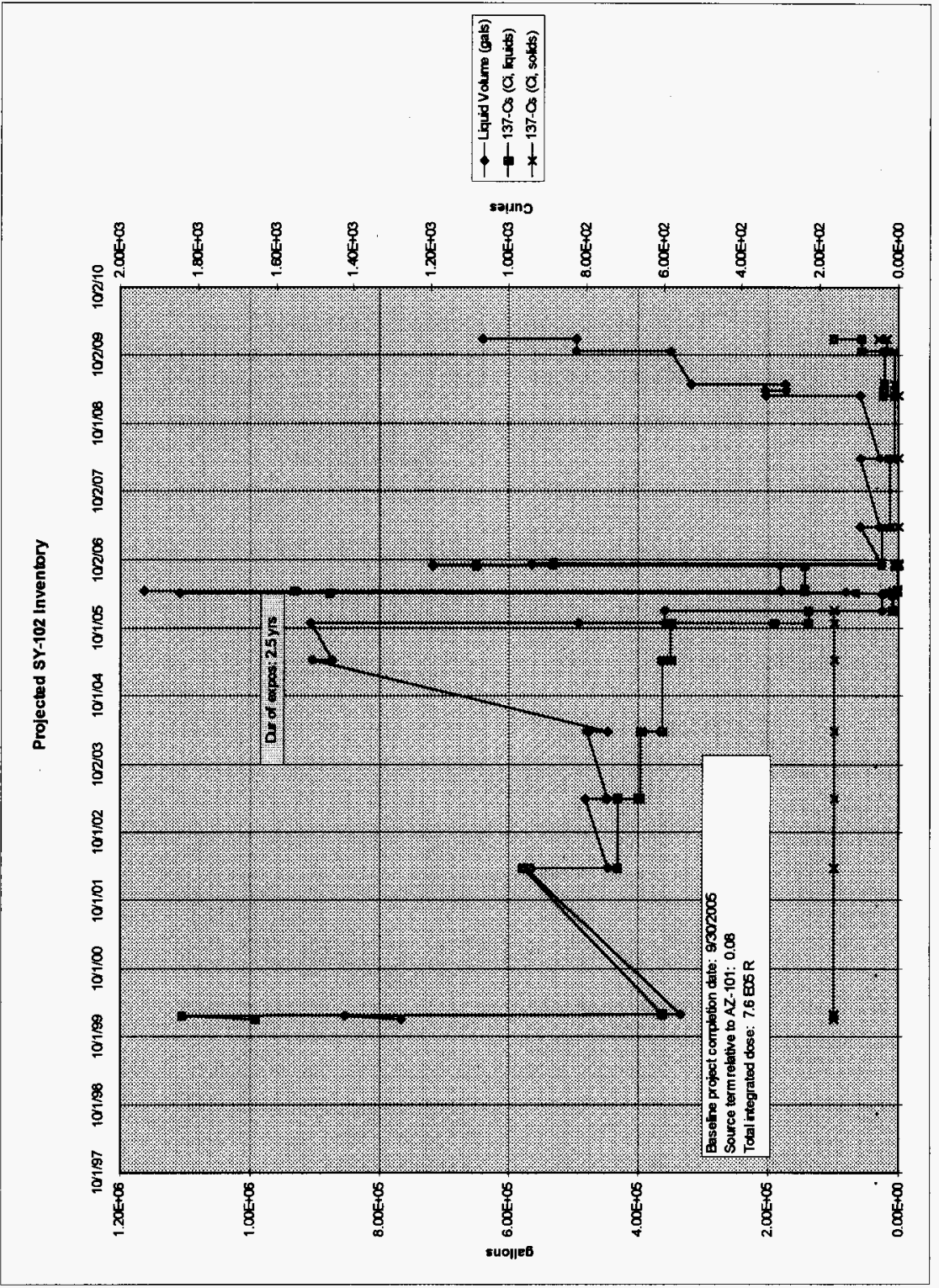


HNF-2004

Revision 0

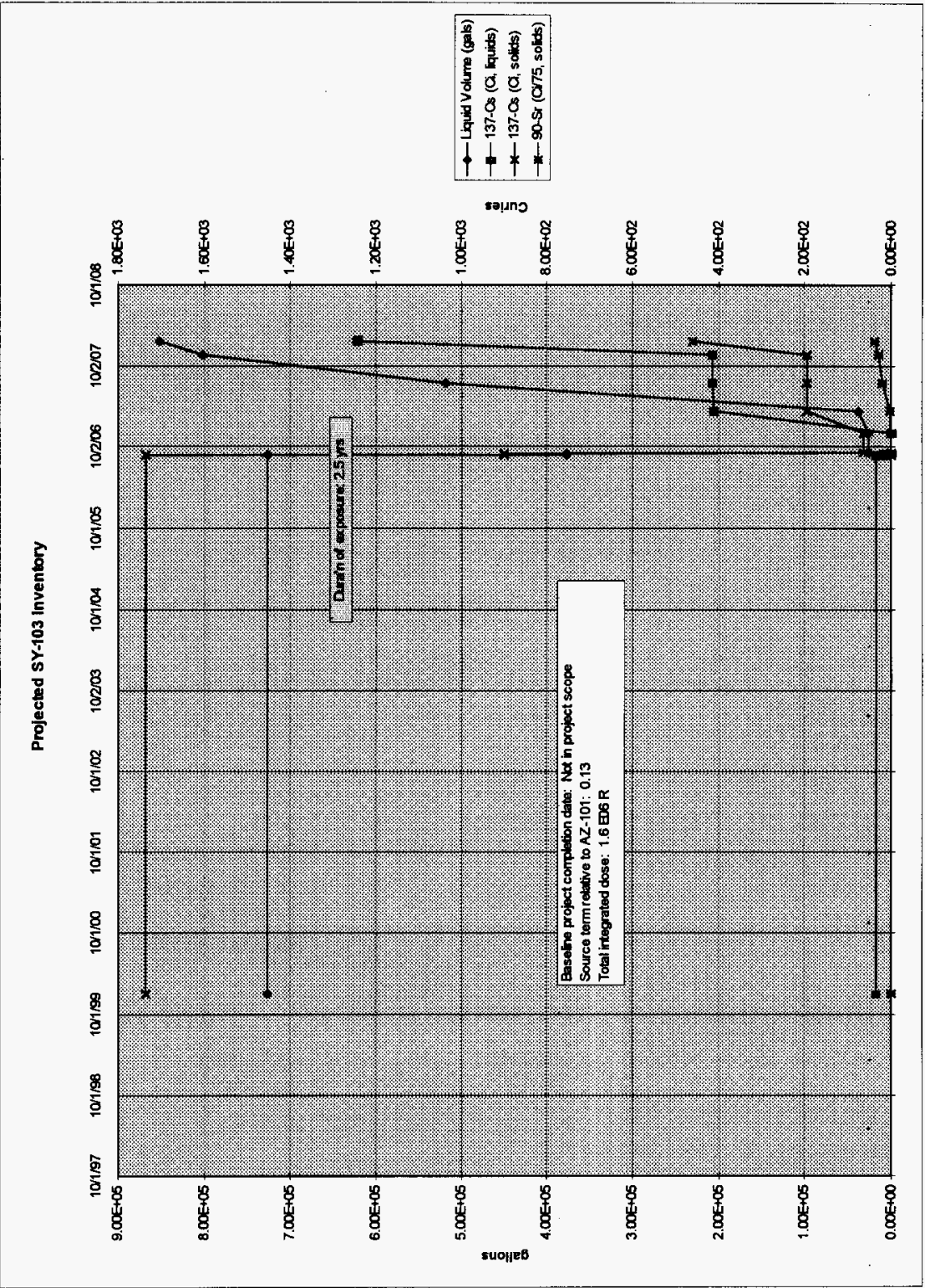




\section{DISTRIBUTION SHEET}

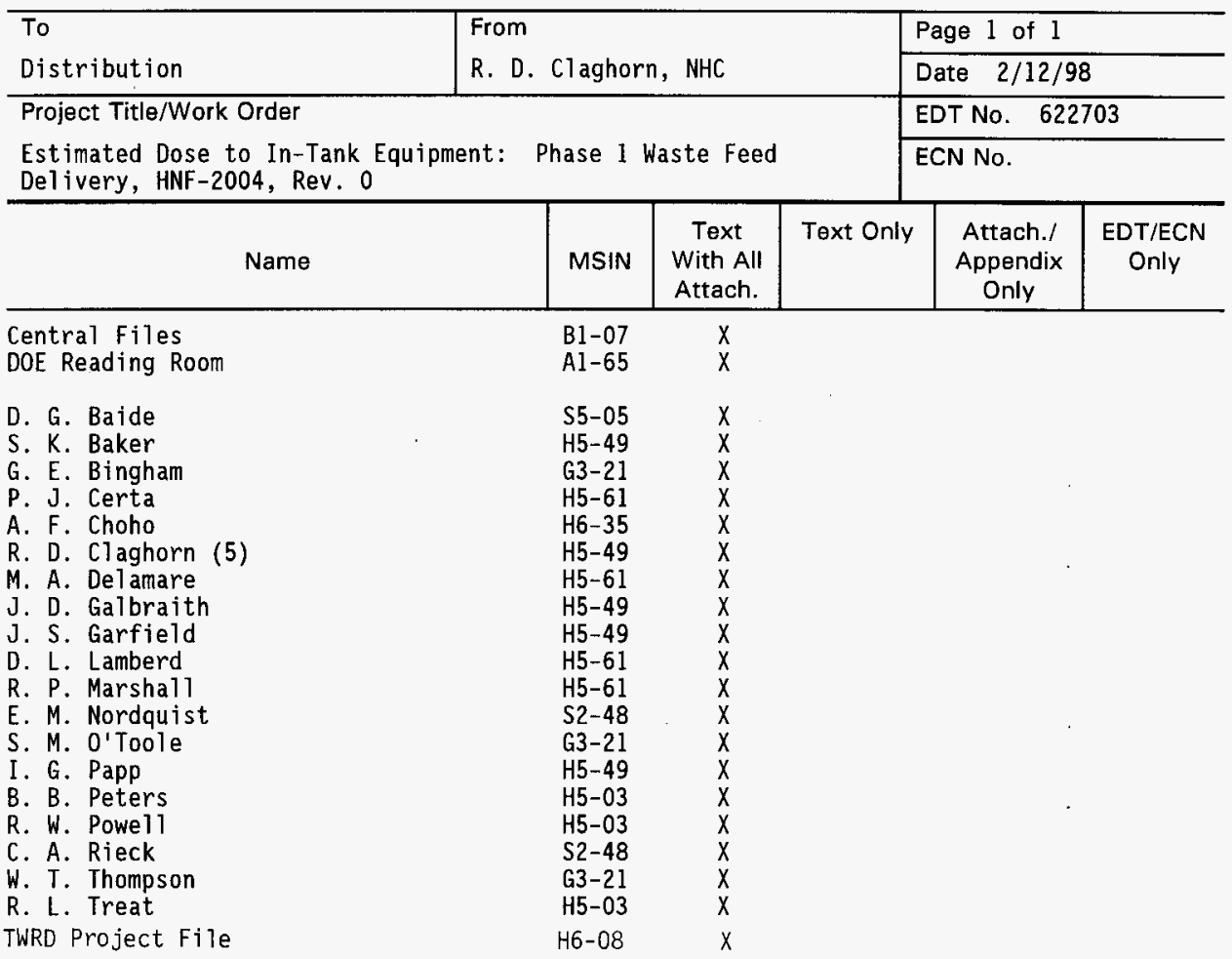

